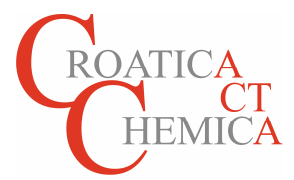

\title{
Iron Phosphate Glass-ceramics
}

\author{
Andrea Moguš-Milanković, ${ }^{1, *}$ Ana Šantić, Luka Pavić, Kristina Sklepić
}

\author{
Ruđer Bošković Institute, Division of Materials Chemistry, HR-10000 Zagreb, Croatia \\ * Corresponding author's e-mail address: mogus@irb.hr \\ RECEIVED: October 8, 2015 * REVISED: October 29, 2015 * ACCEPTED: November 2, 2015
}

THIS PAPER IS DEDICATED TO DR. SVETOZAR MUSIĆ ON THE OCCASION OF HIS 70 ${ }^{\mathrm{TH}}$ BIRTHDAY

\begin{abstract}
The crystallization of $40 \mathrm{Fe}_{2} \mathrm{O}_{3}-60 \mathrm{P}_{2} \mathrm{O}_{5}, 10 \mathrm{ZnO}-30 \mathrm{Fe}_{2} \mathrm{O}_{3}-60 \mathrm{P}_{2} \mathrm{O}_{5}$ and $(43.3-x) \mathrm{PbO}-(13.7+x) \mathrm{Fe}_{2} \mathrm{O}_{3}-43 \mathrm{P}_{2} \mathrm{O}_{5},(0<x<30)$, glasses and glassceramic have been investigated. The structural evolution of glasses during heat treatment at various temperatures and the tendency for crystallization for series of glasses with modified composition are characterized by a dendrite-like phase separation in the early stage of crystallization. Such a behavior leads to the formation of randomly dispersed agglomerates which contain the anhedrally shaped crystallites embedded in glass matrix. Therefore, regardless of the type of crystallization, controlled or spontaneous, the formation of crystalline phases in these phosphate glasses and glass-ceramics is attributed to the disordered interfaces between crystalline grains and glassy matrix.
\end{abstract}

Keywords: iron phosphate glass, iron phosphate glass-ceramics, Raman spectroscopy, X-ray diffraction, scanning electron microscopy.

\section{INTRODUCTION}

$\mathbf{P}$ HOSPHATE glasses are interesting from a scientific and technological point of view due to their specific physical properties such as low melting and glass transition temperatures, high thermal expansions coefficients, high ultra-violet transmission, high electrical conductivity and compositional flexibility, ${ }^{[1-3]}$ Therefore, they are useful for a wide range of applications such as laser hosts, solid electrolytes, photoconductors and materials for nuclear waste immobilization.

The physical and chemical properties of phosphate glasses can be optimized by controlling the melting conditions and chemical composition. The poor chemical durability of phosphate glasses can be significantly enhanced by the addition of the $\mathrm{Fe}_{2} \mathrm{O}_{3} \cdot{ }^{[4-6]}$ As a result, the iron phosphate glasses are of the great interest for several technological and biological applications, ${ }^{[7,8]}$ The structure of the phosphate glass is based on corner-sharing $\mathrm{PO}_{4}$ tetrahedra which form chains, rings or isolated $\mathrm{PO}_{4}$ groups. With the addition of $\mathrm{Fe}_{2} \mathrm{O}_{3}$ to a phosphate glass, the $\mathrm{P}-\mathrm{O}-\mathrm{P}$ bonds are replaced by more chemically durable $\mathrm{P}-\mathrm{O}-\mathrm{Fe}^{2+}$ and/or $\mathrm{P}-\mathrm{O}-\mathrm{Fe}^{3+}$ bonds. ${ }^{[5,9]}$ In these glasses iron commonly exists in two valence states, as $\mathrm{Fe}^{2+}$ and $\mathrm{Fe}^{3+}$ and the $\mathrm{Fe}^{2+} \Leftrightarrow \mathrm{Fe}^{3+}$ equilibrium depends upon the melting atmosphere and the batch composition. ${ }^{[10,11]}$

On the other hand, the preparation and properties of nanocrystallites embedded into glass matrix have received a considerable interest. ${ }^{[3,12]}$ It was shown that the induced crystallization of glasses results in a wide range of glass-ceramics with superior properties useful for different technical applications. The transformation takes place by controlled process of nucleation and crystallites growth which gives rise to the new class of glass-ceramics. ${ }^{[13]}$ However, details of the formation of crystalline phases in glass matrices and its influence on the various properties are hardly known. Glass-ceramics have a number of advantages over parent glasses such as high thermal and chemical stability, high mechanical strength and optical transparency. ${ }^{[14]}$ Few papers about induced crystallization in iron phosphate glasses ${ }^{[6,15]}$ and zinc iron phosphate glasses ${ }^{[16-19]}$ have been reported. However, there is a lack of the reports about the influences of crystallization on the properties of these glasses. Therefore, the main explanation which might contribute to understanding and developing of such new nano- and microcrystalline materials produced by controlled crystallization is still missing.

In this paper our interest is to investigate the influence of induced and spontaneous crystallization on structural properties of three types of phosphate glasses. ${ }^{[20-22]}$ The binary iron phosphate glass of the composition $40 \mathrm{Fe}_{2} \mathrm{O}_{3}-60 \mathrm{P}_{2} \mathrm{O}_{5}(\mathrm{~mol} \%)$ and zinc iron phosphate $10 \mathrm{ZnO}-$ $30 \mathrm{Fe}_{2} \mathrm{O}_{3}-60 \mathrm{P}_{2} \mathrm{O}_{5}(\mathrm{~mol} \%)$ glasses were heat treated in air at 
various temperatures to produce glass-ceramics, whereas lead-iron phosphate glasses with composition (43.3- $x$ ) PbO$(13.7+x) \mathrm{Fe}_{2} \mathrm{O}_{3}-43.0 \mathrm{P}_{2} \mathrm{O}_{5},(0 \leq x \leq 30)$, (mol\%) tends to crystallized spontaneously during cooling and annealing. ${ }^{[20-21]}$ For the latest glasses the structural modifications were obtained by replacing of $\mathrm{PbO}$ with $\mathrm{Fe}_{2} \mathrm{O}_{3}$. To investigate the crystalline phases formed in the crystallized $40 \mathrm{Fe}_{2} \mathrm{O}_{3}-60 \mathrm{P}_{2} \mathrm{O}_{5}$ and $10 \mathrm{ZnO}-$ $30 \mathrm{Fe}_{2} \mathrm{O}_{3}-60 \mathrm{P}_{2} \mathrm{O}_{5}$ along with the thermal stability of the leadiron phosphate glasses, the thermal analysis (DTA), X-ray diffraction (XRD) and Raman spectroscopy have been used. The objective was to study the correlation between the structural modifications in glasses during induced or spontaneous crystallization.

\section{EXPERIMENTAL PROCEDURE}

\section{Glass Preparation}

Iron phosphate glass with composition $40 \mathrm{Fe}_{2} \mathrm{O}_{3}-60 \mathrm{P}_{2} \mathrm{O}_{5}$ (mol\%) was prepared by melting homogeneous mixture of reagent grade $\mathrm{Fe}_{2} \mathrm{O}_{3}$ and $\mathrm{NH}_{4} \mathrm{H}_{2} \mathrm{PO}_{4}$ at $1423 \mathrm{~K}$, zinc iron phosphate glasses, $10 \mathrm{ZnO}-30 \mathrm{Fe}_{2} \mathrm{O}_{3}-60 \mathrm{P}_{2} \mathrm{O}_{5}$ (mol\%), by melting mixture of $\mathrm{ZnO}, \mathrm{Fe}_{2} \mathrm{O}_{3}$ and $\mathrm{NH}_{4} \mathrm{H}_{2} \mathrm{PO}_{4}$ at $1373 \mathrm{~K}$ whereas $(43.3-x) \mathrm{PbO}-(13.7+x) \mathrm{Fe}_{2} \mathrm{O}_{3}-43.0 \mathrm{P}_{2} \mathrm{O}_{5},(0 \leq x \leq 30)$, (mol\%) glasess from appropriate mixture of $\mathrm{PbO}, \mathrm{Fe}_{2} \mathrm{O}_{3}$ and $\mathrm{NH}_{4} \mathrm{H}_{2} \mathrm{PO}_{4}$ at $1373-1473 \mathrm{~K}$. All glasses were prepared in dense alumina silicate crucibles in air for $2 \mathrm{~h}$. The melts were quenched in air by pouring it into a steel mold to form $1 \mathrm{~cm} \times 1 \mathrm{~cm} \times 5 \mathrm{~cm}$ glass bars and subsequently annealed at $723 \mathrm{~K}$ for $4 \mathrm{~h}$. For structural studies and thermal treatments, samples were cut from annealed bar to thick discs. The detailed preparation procedures for all glass systems have been already published. ${ }^{20-22]}$

The thermal properties of glasses investigated in this paper were analysed using differential thermal analysis (DTA) to determine the glass transition, $T_{\mathrm{g}}$, and the crystallization temperatures, $T_{\mathrm{C}}$. The measurements were performed in air with different heating rates, from 10 to $20 \mathrm{~K} \mathrm{~min}^{-1}$. The estimated error is $\pm 2 \mathrm{~K}$. The glass samples were crystallized for 24 hours by heating at temperatures corresponding to their DTA crystallization peaks.

The glasses $40 \mathrm{Fe}_{2} \mathrm{O}_{3}-60 \mathrm{P}_{2} \mathrm{O}_{5}$ and $10 \mathrm{ZnO}-30 \mathrm{Fe}_{2} \mathrm{O}_{3}-$ $60 \mathrm{P}_{2} \mathrm{O}_{5}$ were heat treated in air at various temperatures near $T_{\mathrm{g}}, T_{\mathrm{C} 1}$ and $T_{\mathrm{C} 2}$. After each heat treatment the samples were cooled down to room temperature and the structural and electrical properties were examined.

\section{Structural Investigation: XRD, Raman, SEM}

The X-ray diffraction (XRD) data were obtained using two different diffractometers: Philips model PW 1820 and $X^{\prime}$ Pert MPD for $10 \mathrm{ZnO}-30 \mathrm{Fe}_{2} \mathrm{O}_{3}-60 \mathrm{P}_{2} \mathrm{O}_{5}$, and $40 \mathrm{Fe}_{2} \mathrm{O}_{3}-60 \mathrm{P}_{2} \mathrm{O}_{5}$, respectively ( $\mathrm{CuK \alpha}$ radiation, Bragg-Brentano geometry).
Intensity data were collected at room temperature (RT) in the $2 \theta$ angle range of $10-70^{\circ}$ with $0.02^{\circ}$ step width. Crystalline phase identification was done using the ICDD-PDF database. The amount of the crystalline phases was determined by the Rietveld method using an internal standard, $\mathrm{TiO}_{2}$ and $\mathrm{MgO}$ powder for $40 \mathrm{Fe}_{2} \mathrm{O}_{3}-60 \mathrm{P}_{2} \mathrm{O}_{5}$ and $10 \mathrm{ZnO}-30 \mathrm{Fe}_{2} \mathrm{O}_{3}-60 \mathrm{P}_{2} \mathrm{O}_{5}$ glasses respectively. Rietveld analysis was performed with commercial software X'Pert HighScore (Plus).

The Raman spectra for all glass and thermally treated samples were obtained using a computerized triple monochromator HORIBA JOBIN YVON model T64000 (Paris, France). The recorded Raman spectra were deconvoluted using a symmetric Gaussian function. The structural units in phosphate network were classified according to their connectivities by $Q^{n}$ notation, where $n$ represents the number of bridging oxygen atoms per $\mathrm{PO}_{4}$ tetrahedron $(n=0-3)$.

The microstructure of glasses and crystallized samples was evaluated by scanning electron microscope, SEM. Samples were not coated with an electrically conductive layer and the accelerating voltage was kept low. The detailed description of experimental techniques used in this paper is reported elsewhere. ${ }^{[20-22]}$

\section{RESULTS AND DISCUSSION}

\section{DTA Analysis}

DTA patterns for the $40 \mathrm{Fe}_{2} \mathrm{O}_{3}-60 \mathrm{P}_{2} \mathrm{O}_{5}$ glass obtained with different heating rates $\left(10,15\right.$ and $\left.20 \mathrm{~K} \mathrm{~min}^{-1}\right)$, shown in Figure 1 are typical for all iron phosphate glasses. ${ }^{[20]}$ The endothermic phenomenon at $\approx 790 \mathrm{~K}$ is related to glass transition, $T_{\mathrm{g}}$, and is followed by the two exothermic peaks at $\approx 910 \mathrm{~K}$ and $\approx 1070 \mathrm{~K}$ that are ascribed to the crystallization temperatures, $T_{\mathrm{C} 1}$ and $T_{\mathrm{C} 2}$. The $T_{\mathrm{C} 1}$ and $T_{\mathrm{C} 2}$

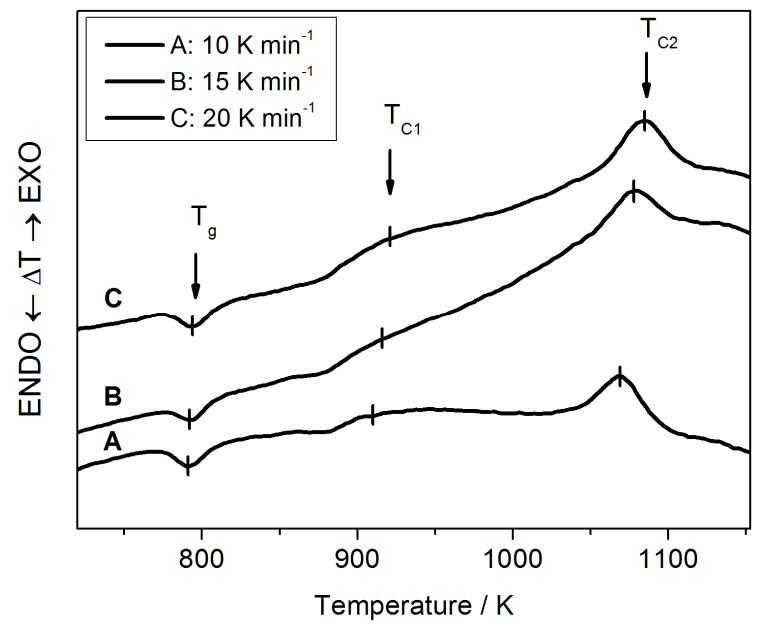

Figure 1. Differential thermal analysis (DTA) for the $40 \mathrm{Fe}_{2} \mathrm{O}_{3}-$ $57 \mathrm{P}_{2} \mathrm{O}_{5}$ glass with different heating rates (from Ref. [20]). 


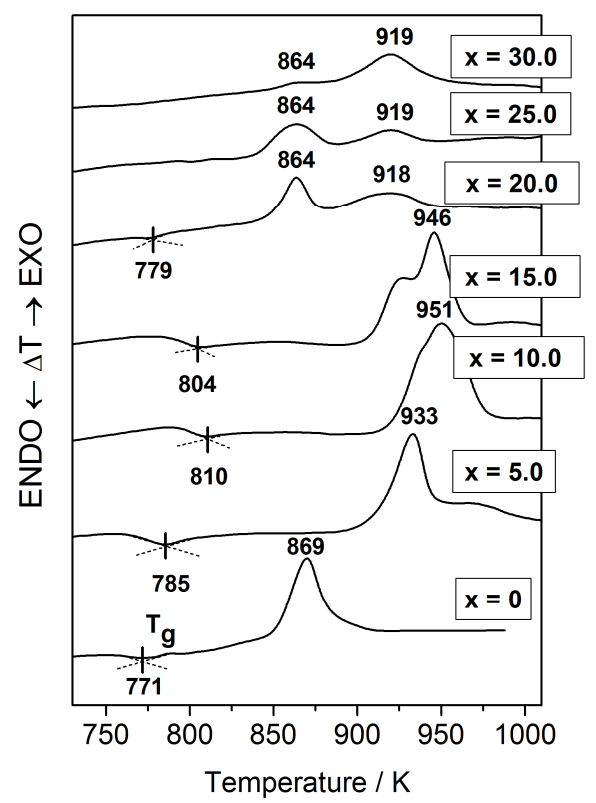

Figure 2. Differential thermal analysis (DTA) curves for the $(43.3-x) \mathrm{PbO}-(13.7+x) \mathrm{Fe}_{2} \mathrm{O}_{3}-43 \mathrm{P}_{2} \mathrm{O}_{5},(0<x<30)$, glasses and partially crystallized samples (from Ref. [22]).

peaks have been attributed to the formation of dominant $\mathrm{Fe}_{3}\left(\mathrm{P}_{2} \mathrm{O}_{7}\right)_{2}$ and $\mathrm{Fe}_{4}\left(\mathrm{P}_{2} \mathrm{O}_{7}\right)_{3}$ crystalline phases, respectively. Although there are no significant changes in the DTA patterns with change of heating rate, the temperatures of peaks are slightly shifted to higher temperatures with

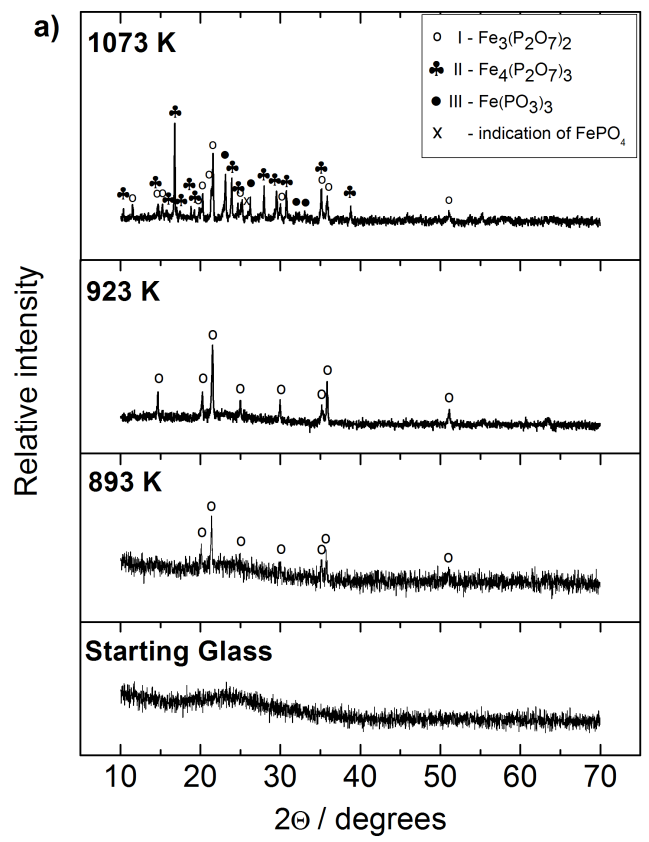

increasing heating rates.

For lead iron phosphate glasses which are simultaneously crystallized during cooling the DTA patterns are shown in Figure 2. It should be mentioned that in this glass series the DTA patterns are related to the changes in the glass composition. As can been seen from Figure 2 the small endothermic peaks related to the $T_{\mathrm{g}}$ for glasses containing up to $28.7 \mathrm{Fe}_{2} \mathrm{O}_{3}$ increases from 771 to $810 \mathrm{~K}$ whereas two exothermic peaks in the range between 864 and $951 \mathrm{~K}$ are result of the crystallization of various pyrophosphate $\left(Q^{1}\right)$ and orthophosphate $\left(Q^{0}\right)$ structures that are determined by Raman spectroscopy and XRD.

\section{XRD Analysis}

In order to investigate structural changes after each heat treatment, the series of XRD measurements were performed on powdered samples of $40 \mathrm{Fe}_{2} \mathrm{O}_{3}-60 \mathrm{P}_{2} \mathrm{O}_{5}$ and $10 \mathrm{ZnO}-30 \mathrm{Fe}_{2} \mathrm{O}_{3}-60 \mathrm{P}_{2} \mathrm{O}_{5}$ glasses at different stages of crystallization process. Figure $3(\mathrm{a})$ shows the XRD patterns of $40 \mathrm{Fe}_{2} \mathrm{O}_{3}-60 \mathrm{P}_{2} \mathrm{O}_{5}$ glass heat-treated at 893, 923 and 1073 K. [20] The results of XRD investigations on heat treated $10 \mathrm{ZnO}-30 \mathrm{Fe}_{2} \mathrm{O}_{3}-60 \mathrm{P}_{2} \mathrm{O}_{5}$ glass at $793,893,953,963$ and $1033 \mathrm{~K}$ for 24 hours are shown in Figure 3(b). The XRD patterns of starting glasses show only a wide halo characteristic for the amorphous state, whereas XRD patterns of glass-ceramics show the changes upon heattreatment.

XRD patterns collected for $40 \mathrm{Fe}_{2} \mathrm{O}_{3}-60 \mathrm{P}_{2} \mathrm{O}_{5}$ glass heat-treated at 893 and $923 \mathrm{~K}$, Figure 3(a), contain

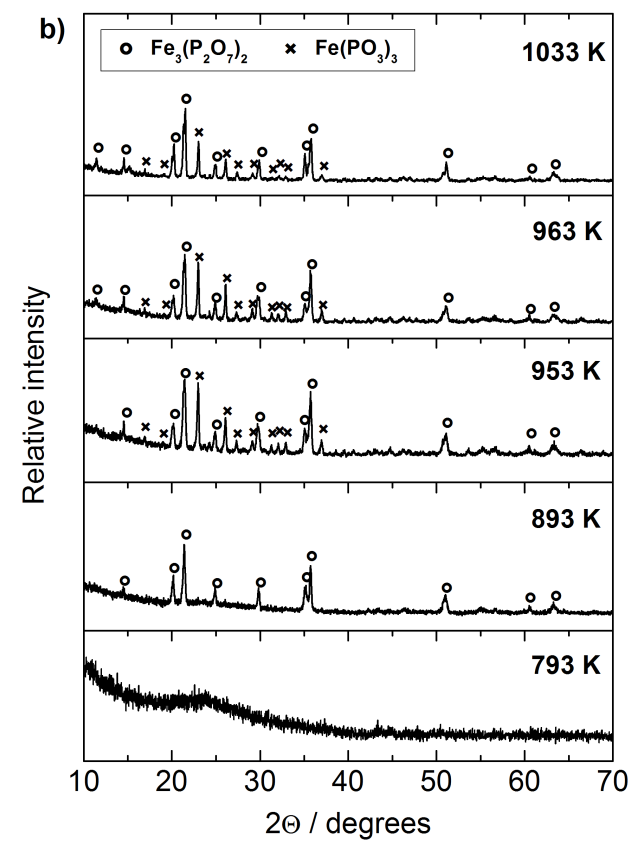

Figure 3. X-ray diffraction patterns for heat-treated: $40 \mathrm{Fe}_{2} \mathrm{O}_{3}-57 \mathrm{P}_{2} \mathrm{O}_{5}$ (a) and $10 \mathrm{ZnO}-30 \mathrm{Fe}_{2} \mathrm{O}_{3}-60 \mathrm{P}_{2} \mathrm{O}_{5}$ glass (b) (from Refs. $[20,21])$. 
Table 1. Crystallinity for the $40 \mathrm{Fe}_{2} \mathrm{O}_{3}-60 \mathrm{P}_{2} \mathrm{O}_{5}$ and $10 \mathrm{ZnO}-$ $30 \mathrm{Fe}_{2} \mathrm{O}_{3}-57 \mathrm{P}_{2} \mathrm{O}_{5}$ glass heat-treated at various temperatures

\begin{tabular}{cc}
\hline $\begin{array}{c}\text { Heat-treatment } \\
\text { temperature } / \mathrm{K}\end{array}$ & $\begin{array}{c}\text { Crystallinity, } \\
\mathrm{W} / \%( \pm 1 \%)\end{array}$ \\
\hline $40 \mathrm{Fe}_{2} \mathrm{O}_{3}-60 \mathrm{P}_{2} \mathrm{O}_{5}$ & - \\
- & 7 \\
893 & 34 \\
923 & 82 \\
1073 & \\
\hline $10 \mathrm{ZnO}-30 \mathrm{Fe}_{2} \mathrm{O}_{3}-60 \mathrm{P}_{2} \mathrm{O}_{5}$ & - \\
- & - \\
793 & 27 \\
893 & 52 \\
953 & 49 \\
963 & 57 \\
1033 &
\end{tabular}

diffraction lines that correspond to the crystalline phase $\mathrm{Fe}_{3}\left(\mathrm{P}_{2} \mathrm{O}_{7}\right)_{2}$. Diffraction lines are superimposed on a halo indicating relatively high amount of glassy phase. Shape and intensity of diffraction lines in XRD pattern of the glass heattreated at $923 \mathrm{~K}$, which is slightly above $T_{\mathrm{C} 1}$, are more pronounced indicating a higher amount of crystalline phase present, Figure 3(a). However, with increasing heat-treatment temperature to $1073 \mathrm{~K}$ (Figure 3(a)) and 953, 963 and $1033 \mathrm{~K}$ (Figure $3(\mathrm{~b})$ ) for $10 \mathrm{ZnO}-30 \mathrm{Fe}_{2} \mathrm{O}_{3}-60 \mathrm{P}_{2} \mathrm{O}_{5}$ glass, in addition to $\mathrm{Fe}_{3}\left(\mathrm{P}_{2} \mathrm{O}_{7}\right)_{2}$, the new dominant crystalline phase is present, $\mathrm{Fe}_{4}\left(\mathrm{P}_{2} \mathrm{O}_{7}\right)_{3}$. For binary $40 \mathrm{Fe}_{2} \mathrm{O}_{3}-60 \mathrm{P}_{2} \mathrm{O}_{5}$ glass some $\mathrm{Fe}\left(\mathrm{PO}_{3}\right)_{3}$ crystalline phase as well as an indication of $\mathrm{FePO}_{4}$ is observed.

It is worth noting that the heat-treatment at $\approx T_{\mathrm{C} 2}$ leads to the massive crystallization with small amount of residual glassy phase according to the Rietveld analysis, given in Table 1 for $40 \mathrm{Fe}_{2} \mathrm{O}_{3}-60 \mathrm{P}_{2} \mathrm{O}_{5}$ and $10 \mathrm{ZnO}-30 \mathrm{Fe}_{2} \mathrm{O}_{3}-60 \mathrm{P}_{2} \mathrm{O}_{5}$ glasses.

For glasses which exhibited spontaneous crystallization the XRD patterns of partially crystallized glasses contain lines that correspond to the $\mathrm{Fe}_{3}\left(\mathrm{P}_{2} \mathrm{O}_{7}\right)_{2}, \mathrm{Fe}_{7}\left(\mathrm{PO}_{4}\right)_{6}$, $\mathrm{Fe}_{2} \mathrm{~Pb}_{3}\left(\mathrm{PO}_{4}\right)_{4}$ phases, see Figure 4 . It seems that the crystallization tendency for this series of glasses increases with increasing $\mathrm{Fe}_{2} \mathrm{O}_{3}$ content from 28.7 to 43.7 (mol\%). Since in these glasses $\mathrm{PbO}$ is replaced by $\mathrm{Fe}_{2} \mathrm{O}_{3}$, the $\mathrm{O} / \mathrm{P}$ ratio increases which in turns causes the reduction of length of phosphate chains. Such a behavior is responsible for both, the formation of diverse pyrophosphate and orthophosphate crystalline phases and the higher tendency for devitrification.

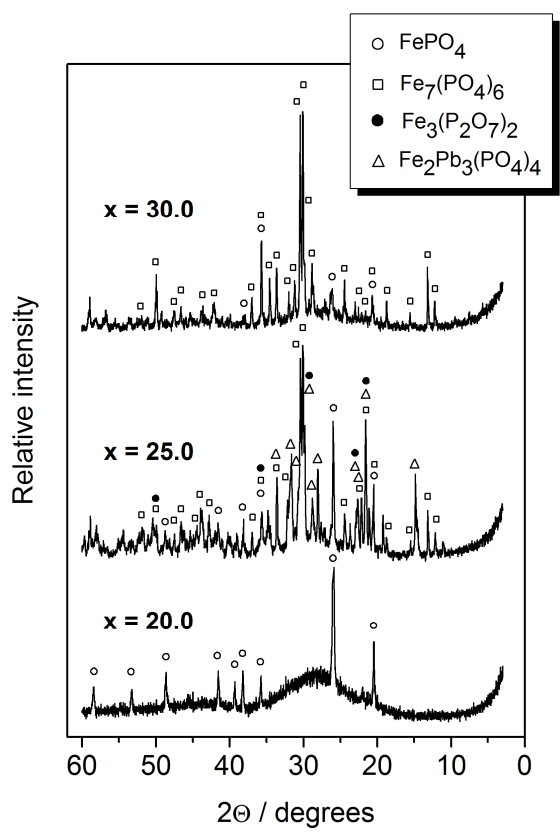

Figure 4. X-ray diffraction patterns for $(43.3-x) \mathrm{PbO}$ $(13.7+x) \mathrm{Fe}_{2} \mathrm{O}_{3}-43 \mathrm{P}_{2} \mathrm{O}_{5}, \quad(0<x<30), \quad$ partially crystallized glasses.[20]

\section{Raman Spectroscopy}

The evolution of Raman spectra of heat treated glasses at various temperatures is exhibited in Figure 5(a) and (b) for $10 \mathrm{ZnO}-30 \mathrm{Fe}_{2} \mathrm{O}_{3}-60 \mathrm{P}_{2} \mathrm{O}_{5}$ glass. The similar effect of heat treatment on microstructural changes for $40 \mathrm{Fe}_{2} \mathrm{O}_{3}-60 \mathrm{P}_{2} \mathrm{O}_{5}$ glass was observed. [20]

The Raman bands have been assigned using literature data for various glasses and crystalline materials. ${ }^{[6,24,25]}$ Also, crystalline phases formed during heat treatment originate from the dominant phosphate structural units present in the starting glass. Therefore, the Raman bands for as-received glasses fall into similar ranges with the corresponding heat treated samples indicating some structural similarities between glassy and corresponding crystalline compounds.

The Raman band assignments of the starting glass, Figure 5(a), are characteristic for pyrophosphate, $Q^{1}$, structure with the most prominent bands at 1081 and $749 \mathrm{~cm}^{-1}$ related to the symmetric stretching mode of non-bridging $\left(\mathrm{PO}_{3}\right)_{\text {sym }}$ and bridging $(\mathrm{P}-\mathrm{O}-\mathrm{P})_{\text {sym }}$ oxygen atoms, respectively. The low intensity bands at 1215 and $650 \mathrm{~cm}^{-1}$ are attributed to the non-bridging, $\left(\mathrm{PO}_{2}\right)_{\text {sym }}$ and bridging oxygen atoms $(\mathrm{P}-\mathrm{O}-\mathrm{P})_{\text {sym }}$ in $Q^{2}$ phosphate tetrahedra. The shoulder at $940 \mathrm{~cm}^{-1}$ suggests the presence of isolated $Q^{0}$ phosphate units. Low frequency bands $<500 \mathrm{~cm}^{-1}$ are related to the bending modes of different phosphate units along with the $\mathrm{Fe}_{2} \mathrm{O}_{3}$ as modifier. Thus, the basic phosphate network in $10 \mathrm{ZnO}-30 \mathrm{Fe}_{2} \mathrm{O}_{3}-60 \mathrm{P}_{2} \mathrm{O}_{5}$ glass consists predominantly of 

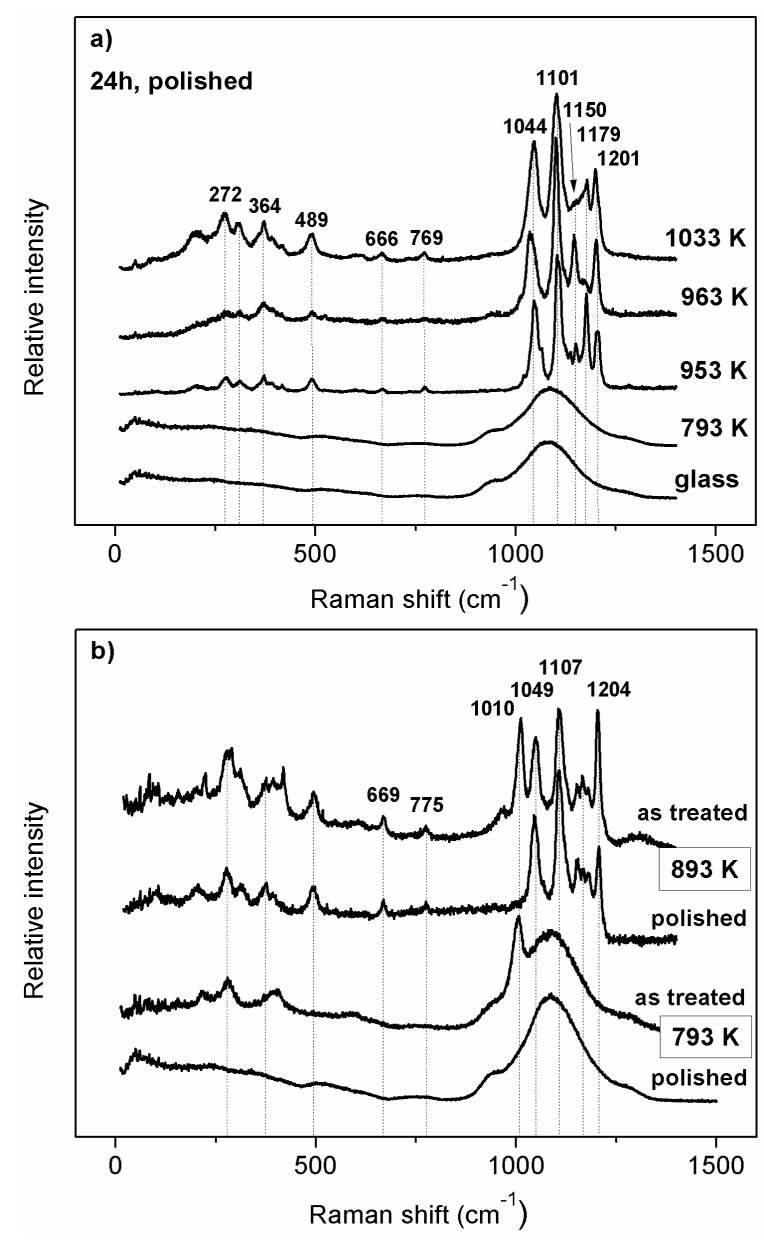

Figure 5. The Raman spectra for $10 \mathrm{ZnO}-30 \mathrm{Fe}_{2} \mathrm{O}_{3}-60 \mathrm{P}_{2} \mathrm{O}_{5}$ : glass and crystallized samples (a) and polished and unpolished samples heat-treated at 793 and $893 \mathrm{~K}$ (b). ${ }^{[21]}$

pyrophosphate $\left(\mathrm{P}_{2} \mathrm{O}_{7}\right)^{4-}$ groups along with a small amount of metaphosphate chains of $\left(\mathrm{PO}_{3}\right)^{-}$groups and isolated orthophosphate $\left(\mathrm{PO}_{4}\right)^{3-}$ groups.

The Raman spectra collected from heat treated glass at higher temperatures from 953 to $1033 \mathrm{~K}$, exhibit sharper bands related to more intense crystals growth. The most intense bands in each spectrum at 1044 and $1101 \mathrm{~cm}^{-1}$ are related to the symmetric stretching mode of non-bridging $\left(\mathrm{PO}_{3}\right)_{\text {sym }}$ oxygens in dimer $\left(\mathrm{P}_{2} \mathrm{O}_{7}\right)^{4-}$ units $\left(\mathrm{Q}^{1}\right)$. The less intense bands at 1150 and $1179 \mathrm{~cm}^{-1}$ are associated to the asymmetric stretching $\left(\mathrm{PO}_{3}\right)_{\text {asym }}$ mode in $Q^{1}$ structure. The appearance of intense band near 1200 $\mathrm{cm}^{-1}$ could be associated to the symmetric stretching nonbridging $\mathrm{PO}_{2}$ mode in $\mathrm{Q}^{2}$ structure. The bands in the region between 773 and $667 \mathrm{~cm}^{-1}$ are due to the symmetric ( $P$ $\mathrm{O}-\mathrm{P})_{\text {sym }}$ bridging mode in $\mathrm{Q}^{1}$ and $\mathrm{Q}^{2}$ tetrahedra, respectively. The low intensity bands between 200 and $500 \mathrm{~cm}^{-1}$ are related to the bending modes of different phosphate units along with the $\mathrm{ZnO}$ and $\mathrm{Fe}_{2} \mathrm{O}_{3}$ as the modifiers.

In order to investigate effects of the surface crystallization, the Raman spectra from unpolished samples were also collected. A significant difference was found between the Raman spectra of polished and unpolished samples as it is shown in Figure 5b. Raman spectra for as-treated glass at 793 and $893 \mathrm{~K}$ exhibit an additional intense band at 1010 $\mathrm{cm}^{-1}$ assigned to the symmetric $\mathrm{PO}_{4}$ stretching mode associated with the non-bridging oxygens in $\mathrm{Q}^{0}$ structure. ${ }^{[23]}$ These results indicate that the samples heat treated in air contain crystalline ferric orthophosphate, $\mathrm{FePO}_{4}$, on its surface. ${ }^{[6]}$ However, Raman spectrum from polished sample (removed surface layer) is dominated by the intense bands at 1107 and $1048 \mathrm{~cm}^{-1}$ along with two less intense bands at 1150 and $1177 \mathrm{~cm}^{-1}$ characteristic for the $\mathrm{Fe}_{3}\left(\mathrm{P}_{2} \mathrm{O}_{7}\right)_{2}$ crystalline phase. There is no band at $1010 \mathrm{~cm}^{-1}$ related to the $\mathrm{FePO}_{4}$. It should also be mentioned that the Raman band near $1200 \mathrm{~cm}^{-1}$ could be assigned to the asymmetric $\mathrm{PO}_{3}$ modes of non-bridging $\mathrm{P}-\mathrm{O}$ bond either in $\mathrm{Q}^{1}$ or $\mathrm{Q}^{2}$ structure.

The Raman spectra for series of $(43.3-x) \mathrm{PbO}-$ $(13.7+x) \mathrm{Fe}_{2} \mathrm{O}_{3}-43.0 \mathrm{P}_{2} \mathrm{O}_{5},(0 \leq x \leq 30)$, glasses and partially crystallized glasses are shown in Figure 6 . The assignments of Raman bands are similar to those for $40 \mathrm{Fe}_{2} \mathrm{O}_{3}-60 \mathrm{P}_{2} \mathrm{O}_{5}$ and $10 \mathrm{ZnO}-30 \mathrm{Fe}_{2} \mathrm{O}_{3}-60 \mathrm{P}_{2} \mathrm{O}_{5}$ glasses. However, the evolution of Raman spectra is related to the glass composition changes and exhibits the influence of $\mathrm{Fe}_{2} \mathrm{O}_{3}$ addition on the crystallization processes during cooling. The increase of $\mathrm{Fe}_{2} \mathrm{O}_{3}$ and $\mathrm{O} / \mathrm{P}$ ratio is responsible for depolymerization of phosphate chains along with the increase of the number of non-bridging oxygens. ${ }^{[22]}$ Such a diversity of bridging and nonbridging oxygens which indicates their random configuration is reflected in the glass stability against crystallization. Since various phosphate units are present in these samples, they may be located in distinct pseudophases ${ }^{[26]}$ which in appropriate circumstances are nucleated to form crystalline phases. ${ }^{[27]}$

\section{Scanning Electron Microscopy (SEM)}

For understanding of the glass and crystallized sample structure, the microstructural analysis has been performed by SEM. Figures 7(a), (b) and (c) show the microstructural evolution of heat treated $10 \mathrm{ZnO}-30 \mathrm{Fe}_{2} \mathrm{O}_{3}-$ $60 \mathrm{P}_{2} \mathrm{O}_{5}$ glass.

At low heating temperature, $793 \mathrm{~K}$, there are no major changes of the microstructure except for some barely detectable beginning of the crystallization at the glass surface, Figure7(a).

Glass heat treated at $963 \mathrm{~K}$ for 24 hours is shown in Figures $7(b)$. The inside of the crack is full of the crystalline grains with an average size which varies from 50 to $250 \mathrm{~nm}$, as can be seen in the inset of Figure $7(b)$. The grains do not have regular shape which is typical for crystallites. Such a 


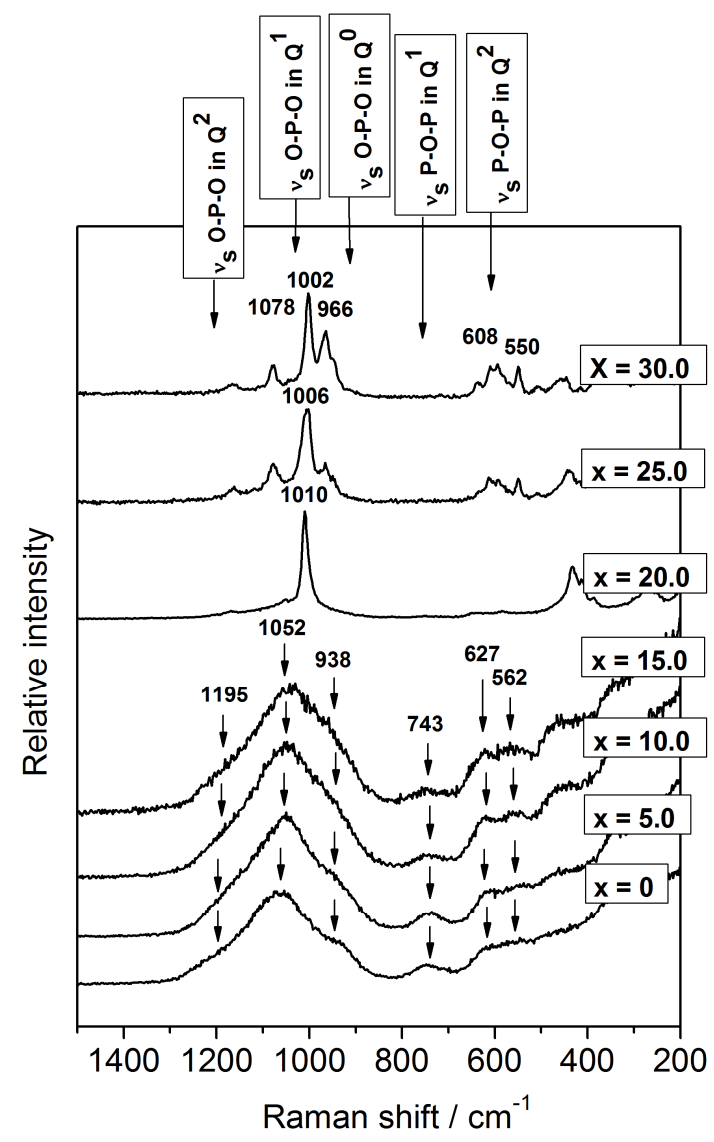

Figure 6. The Raman spectra for series of $(43.3-x) \mathrm{PbO}^{-}$ $(13.7+x) \mathrm{Fe}_{2} \mathrm{O}_{3}-43 \mathrm{P}_{2} \mathrm{O}_{5}, \quad(0<x<30)$, glasses and partially crystallized glasses. ${ }^{[22]}$

small grains formed at about $T_{\mathrm{C} 1}$ have tendency to form agglomerates of crystallites surrounded with a substantial fraction of the residual glassy phase.

The modification of nanostructure is more pronounced after heating at $1033 \mathrm{~K}$, i.e. close to $T_{\mathrm{c} 2}$, Figure $7(\mathrm{c})$. Similarly to the sample heat treated at $T_{\mathrm{C} 1}$ there is still large fraction of residual glassy phase but the crystalline grains are more interconnected through glassy matrix. However, the shape of crystal grains formed in glass matrix is better defined and according to the SEM micrographs their average size varies from 100 to $500 \mathrm{~nm}$. As expected, the better defined crystal-like shape can be distinguished just in a few crystalline grains.

Going further in the interpretation of crystallization in glasses, the SEM micrographs of spontaneously crystallized $(43.3-x) \mathrm{PbO}-(13.7+x) \mathrm{Fe}_{2} \mathrm{O}_{3}-43.0 \mathrm{P}_{2} \mathrm{O}_{5},(0 \leq x \leq 30)$, glasses are analysed, Figures $8(\mathrm{a})$, (b) and (c). As can be seen Figure 8(a) shows homogeneous 28.3PbO-28.7 $\mathrm{Fe}_{2} \mathrm{O}_{3}-$ $43.0 \mathrm{P}_{2} \mathrm{O}_{5}$ glass. According to the XRD patterns, Figure 4, glasses containing up to $33.7 \mathrm{Fe}_{2} \mathrm{O}_{3}$ as well as more than 23.3 $\mathrm{PbO}$ are amorphous. On the other hand, SEM analysis
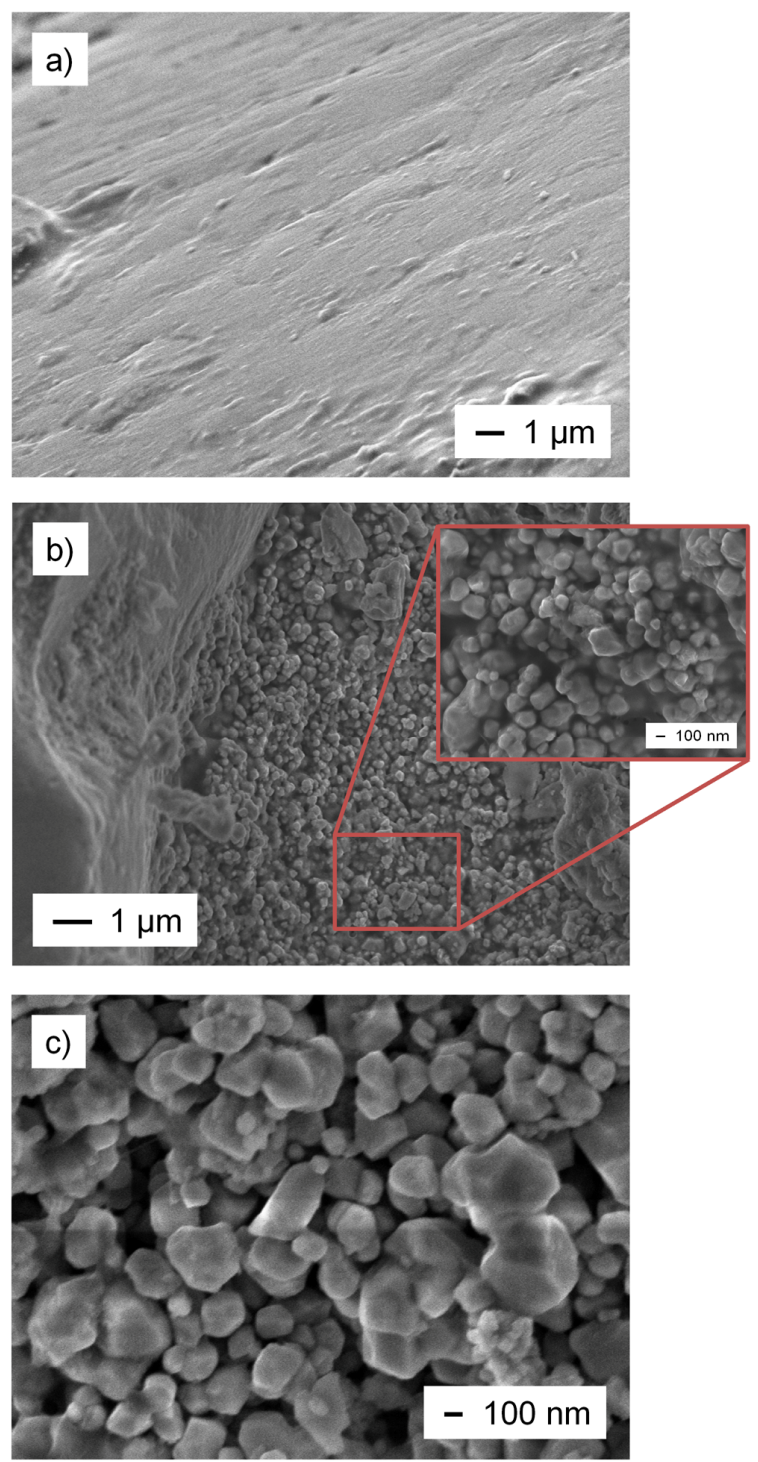

Figure 7. SEM micrographs of $10 \mathrm{ZnO}-30 \mathrm{Fe}_{2} \mathrm{O}_{3}-60 \mathrm{P}_{2} \mathrm{O}_{5}$ glass heat-treated at: $793 \mathrm{~K}(\mathrm{a}), 963 \mathrm{~K}$, inset: crack interior (b) and $1033 \mathrm{~K}(\mathrm{c})$. $^{[21]}$

along with the SEM-EDAX of glasses with higher $\mathrm{Fe}_{2} \mathrm{O}_{3}$ content up to $43.0 \mathrm{~mol} \%$ indicated a presence of crystalline phases as is shown in Figures 8 (b) and (c). It seems that with increasing $\mathrm{Fe}_{2} \mathrm{O}_{3}$ content and O/P ratio, the crystallization tendency is enhanced and crystalline phases such as $\mathrm{Fe}_{3}\left(\mathrm{P}_{2} \mathrm{O}_{7}\right)_{2}, \mathrm{Fe}_{7}\left(\mathrm{PO}_{4}\right)_{6}, \mathrm{Fe}_{2} \mathrm{~Pb}_{3}\left(\mathrm{PO}_{4}\right)_{4}$ appeared in the samples.

For all three glass systems the starting glass is fully amorphous although for controlled crystallization process glasses are heated at about $T_{\mathrm{g}}$. At such a low heating temperature there are no major changes of the microstructure except for some barely detectable beginning of the crystallization at the glass surface which is confirmed by Raman spectroscopy and XRD analysis, Figures 3 and 5. 

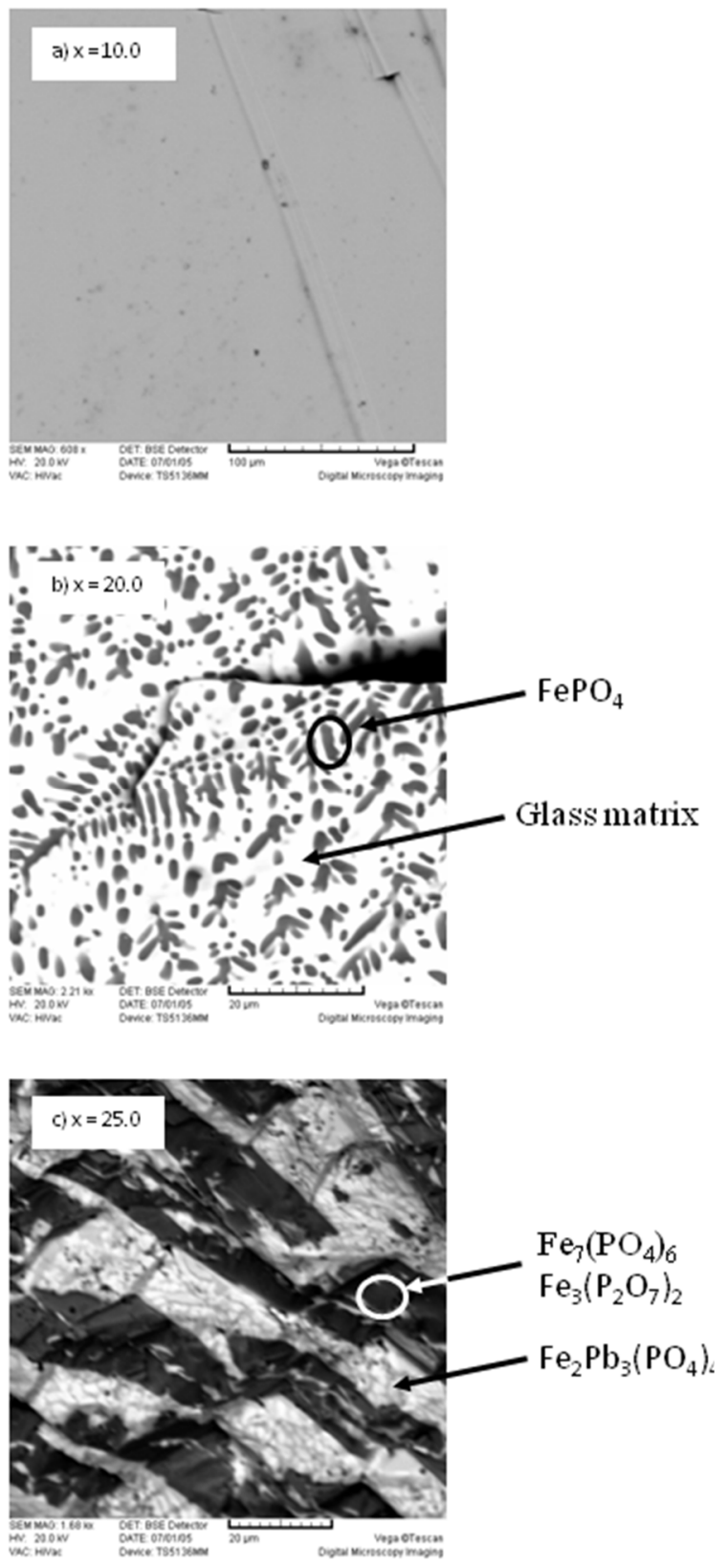

Figure 8. SEM micrographs of $(43.3-x) \mathrm{PbO}^{-}(13.7+x) \mathrm{Fe}_{2} \mathrm{O}_{3}{ }^{-}$ $43 \mathrm{P}_{2} \mathrm{O}_{5},(0<x<30)$, glasses: $28.3 \mathrm{PbO}-28.7 \mathrm{Fe}_{2} \mathrm{O}_{3}-43 \mathrm{P}_{2} \mathrm{O}_{5}$ glass (a) and spontaneously crystallized glasses: $23.3 \mathrm{PbO}-$ 33.7 $\mathrm{Fe}_{2} \mathrm{O}_{3}-43 \mathrm{P}_{2} \mathrm{O}_{5}$ (b) and 8.3PbO-38.7 $\mathrm{Fe}_{2} \mathrm{O}_{3}-43 \mathrm{P}_{2} \mathrm{O}_{5}$ (c). ${ }^{[22]}$

During controlled crystallization glasses pass through a dendrite-like amorphous phase separation which is a common precursor to the crystallization. In this case one of the phases is highly unstable as a glass and precipitates primary crystalline nuclei on heating at the temperature between $T_{\mathrm{g}}$ and $T_{\mathrm{C} 1}$. However, similar behavior is also evidenced for the lead iron phosphate glasses which crystallized spontaneously where on the surface the formation of first $\mathrm{FePO}_{4}$ phase begins. On the other hand, since glassy phase is unstable the crystalline nuclei are formed and along the dendrite interfaces the crystalline phase close in composition to the $\mathrm{Fe}_{3}\left(\mathrm{P}_{2} \mathrm{O}_{7}\right)_{2}$ crystalline phase starts to grow. The same situation was found for controlled crystallization where few sporadically dispersed cracks filled with $\mathrm{Fe}_{3}\left(\mathrm{P}_{2} \mathrm{O}_{7}\right)_{2}$ crystalline grains appeared, Figure $7(\mathrm{~b})$. The other phase remains amorphous, Figure $7(b)$. Such a situation often results in the growth of anhedrally shaped crystals with an internal microstructure that inherits the morphology of the original phase separation ${ }^{22}$. Thus, as heating temperature increases the crystallization along dendrite interfaces goes forwards, which results in the formation of anhedrally shaped crystallites embedded in glass matrix.

This lead to the conclusion that the dendrite-like phase separation, which causes the formation of anhedrally shaped crystallites, is responsible for crystallization in the iron phosphate glasses regardless of the crystallization type, controlled or spontaneous.

Further evolution of the microstructure has a tendency to form agglomerates of crystallites surrounded with a substantial fraction of the residual glassy phase. For heat treated glasses the modification of microstructure is more pronounced after heating at higher temperatures which leads to better defined and more interconnected crystalline grains.

\section{CONSLUSION}

The crystallization, controlled and simultaneous, for three different glass systems, namely: $40 \mathrm{Fe}_{2} \mathrm{O}_{3}-60 \mathrm{P}_{2} \mathrm{O}_{5}, 10 \mathrm{ZnO}-$ $30 \mathrm{Fe}_{2} \mathrm{O}_{3}-60 \mathrm{P}_{2} \mathrm{O}_{5}$ and $(43.3-x) \mathrm{PbO}-(13.7+x) \mathrm{Fe}_{2} \mathrm{O}_{3}-43.0 \mathrm{P}_{2} \mathrm{O}_{5}$, $(0 \leq x \leq 30)$, glasses have been investigated. The results of the structural analysis of $40 \mathrm{Fe}_{2} \mathrm{O}_{3}-60 \mathrm{P}_{2} \mathrm{O}_{5}$ and $10 \mathrm{ZnO}$ $30 \mathrm{Fe}_{2} \mathrm{O}_{3}-60 \mathrm{P}_{2} \mathrm{O}_{5}$ glasses show that the various iron phosphate crystalline phases crystallize depending on the heat treatment temperature. Thermally induced formation of sporadically dispersed agglomerates of $\mathrm{Fe}_{3}\left(\mathrm{P}_{2} \mathrm{O}_{7}\right)_{2}$ nanocrystallites along with the phase-separated interfaces appeared at lower crystallization temperatures between $T_{\mathrm{g}}$ and $T_{\mathrm{C} 1}$. With increasing heating temperature, more pronounced crystallization is characterized by appearance of better defined crystallite shapes and formation of interfacial disordered regions between crystallites boundaries and glassy matrix. Further increase of heating temperature up to $T_{\mathrm{C} 2}$, produces a nanostructure in which $\mathrm{Fe}_{3}\left(\mathrm{P}_{2} \mathrm{O}_{7}\right)_{2}$, $\mathrm{Fe}_{4}\left(\mathrm{P}_{2} \mathrm{O}_{7}\right)_{3}$ and $\mathrm{Fe}\left(\mathrm{PO}_{3}\right)_{3}$ crystals co-exist along with some residual glassy phase. Similarly, the spontaneous crystal lization as a results of changes in glass composition of $(43.3-x) \mathrm{PbO}-(13.7+x) \mathrm{Fe}_{2} \mathrm{O}_{3}-43.0 \mathrm{P}_{2} \mathrm{O}_{5},(0 \leq x \leq 30)$, is also characterized by an amorphous phase separation in the early stage of crystallization followed by massive 
crystallization enhancing the formation of $\mathrm{Fe}_{3}\left(\mathrm{P}_{2} \mathrm{O}_{7}\right)_{2}$, $\mathrm{Fe}_{7}\left(\mathrm{PO}_{4}\right)_{6}, \mathrm{Fe}_{2} \mathrm{~Pb}_{3}\left(\mathrm{PO}_{4}\right)_{4}$ crystalline phases. Clearly, it seems that the dendrite-like phase separation, causes the disruption and inhomogeneity of crystalline network by the formation of anhedrally shaped various phosphate crystallites.

Acknowledgment. This work was supported by the Croatian Science Foundation; project IP-09-2014-5863. The authors are very grateful to Dr. S. Musić for his assistance in the SEM measurements. Kindest thanks to Dr. Ž. Skoko, Prof. M. A. Valente, Prof. M. P. F. Graca and L. Mikac for their assistance in the XRD and Raman measurements.

\section{REFERENCES}

[1] R. K. Brow, J. Non-Cryst. Solids 2000, 263-264, 1.

[2] B. C. Sales, L. A. Boatner, Science 1984, 226, 45.

[3] Y. Abe, H. Hosono, Inorganic Phosphate Materials, Edited by T. Kanazawa. Elsevier, Amsterdam, 1989, p. 124.

[4] D. E. Day, Z. Wu, C. S. Ray, P. Hrma, J. Non-Cryst. Solids 1998, 241, 1

[5] X. Yu, D. E. Day, G. J. Long, R. K. Brow, J. Non-Cryst. Solids 1997, 215, 21.

[6] X. Fang, C. S. Ray, A. Moguš-Milanković, D. E. Day, J. Non-Cryst. Solids 2001, 283, 162.

[7] B. C. Sales, L. A. Boatner, Radioactive Waste Forms for the Future, Eds. W. Lutze, R. C. Ewing, NorthHolland, Amsterdam, 1988, p. 193.

[8] T. Jermoumi, M. Hafid, N. Niegisch, M. Mennig, A. Sabir, N. Toreis, Mater. Res. Bull. 2002, 37, 49.

[9] R. K. Brow, C. M. Arens, X. Yu, D. E. Day, Phys. Chem. Glasses 1994, 35, 132.

[10] C. S. Ray, X. Fang, M. Karabulut, G. K. Matasinghe, D. E. Day A., J. Non-Cryst. Solids 1999, 249, 1.
[11] G. K. Marasinghe, M. Karabulut, C. S. Ray, D. E. Day, M. G. Shumsky,W. B. Yelon, C. H. Booth, P. G. Allen, D. K. Shuh, J. Non-Cryst. Solids 1997, 222, 144.

[12] Y. Ohta, M. Kitayama, K. Kaneko, S. Toh, F. Shimiz, K. Morinaga, J. Amer. Ceram. Soc. 2005, 88, 1634.

[13] T. Berthier, V. M. Fokin, E. D. Zanotto, J. Non-Cryst. Solids 2008, 354, 1721.

[14] P. W. McMillan, Glass-Ceramics, Academic Press, New York, 1979.

[15] J. E. Garbarczyk, M. Wasiucionek, P. Jozwiak, J. L. Nowinski, C. M.Julien, Solid State lonics 2009, 180, 531.

[16] A. Moguš-Milanković, V. Ličina, S. T. Reis, D. E. Day, J. Non-Cryst. Solids 2007, 353, 2659.

[17] V. Ličina, A. Moguš-Milanković, S. T. Reis, D. E. Day, J. Non-Cryst. Solids 2007, 353, 4395.

[18] S. T. Reis, A. Moguš-Milanković, V. Ličina, J. B. Yang, M. Karabulut, D. E. Day, R. K. Brow, J. Non-Cryst. Solids 2007, 353, 151.

[19] M. Karabulut, B. Yuce, O. Bozdogan, H. Ertap, G. M. Mammedov, J. Non-Cryst. Solids, 2011, 357, 1455.

[20] L. Pavić, M. P. F. Graca, Ž. Skoko, A. Moguš-Milanković, M. A. Valente, J. Amer. Ceram. Soc. 2014, 97, 2517.

[21] A. Moguš-Milanković, K. Sklepić, Ž. Skoko, L. Mikac, S. Musić, D. E. Day, J. Amer. Ceram. Soc. 2012, 95, 303.

[22] A. Moguš-Milanković, A. Šantić, S. T. Reis, K. Furić, D. E. Day, J. Non-Cryst. Solids 2005, 351, 3246.

[23] C. M. Burba, J. M. Palmer, B. S. Holinsworth, J. Raman Spectrosc., 2009, 40, 225.

[24] C. Nelson, D. R. Tallant, J. Phys. Chem. Glasses, 1985, 26, 119.

[25] A. Moguš-Milanković, D. E. Day, B. Pivac, K. Furić, Phys. Chem. Glasses, 1997, 38, 74.

[26] E. A. Porai-Koshits, J. Non-Cryst-Solids, 1985, 73, 79.

[27] M. D. Ingram, G. D. Chryssikos, E. I. Komitsos, J. NonCryst. Solids 1991, 131-133, 1089. 